\title{
An Assessment of the Awareness Pattern of Consumers about American Food Restaurants in Bengaluru City, India
}

\author{
Pooja S. Bhat ${ }^{1 *}$, T.N. Venkata Reddy ${ }^{2}$ and P.K. Mandanna ${ }^{2}$ \\ ${ }^{I}$ Department of Agricultural and Rural Management, Tamil Nadu Agricultural University, \\ Coimbatore - 641003, Tamil Nadu, India \\ ${ }^{2}$ Department of Agricultural Marketing, Co-operation and Business Management, University \\ of Agricultural Sciences, GKVK, Bengaluru - 560 065, Karnataka, India \\ *Corresponding author
}

\section{A B S T R A C T}

\begin{tabular}{l} 
Key w o r d s \\
American Food \\
Restaurants, Fast \\
foods, \\
patronization, \\
Awareness, Brand \\
\hline Article Info \\
$\begin{array}{l}\text { Accepted: } \\
\text { 10 December } 2017 \\
\text { Available Online: } \\
\text { 10 January } 2018\end{array}$ \\
\hline
\end{tabular}

Keywords

American Food

Restaurants, Fast

foods,

patronization,

Awareness, Brand

\section{Article Info}

Accepted:

Available Online:

\begin{abstract}
Today's consumers have exhaustive options and are literally spoilt for choice when it comes to choosing from where to dine out in the food service industry. American Food Restaurants (AFR) are niche restaurants that have convenient locations, quick and efficient services, easily transportable food, good flavours, clean venues and giveaways. The study unearths consumer's awareness of the different brands of AFR's, sources of information about American foods and AFR's in Bengaluru city. Results obtained from 90 respondents have revealed that cent per cent of the consumers consume outside food. Other than dining out at AFR's, consumers also dined at Ethnic restaurants and Chinese restaurants. Among the consumers patronizing American foods, two-thirds of the consumers were relying on information from advertisements followed by internet, point of display at the restaurant, television and friends/ relatives as the major sources of information. This study will be helpful for the new entrants in the food service sector particularly for the local brands and future potential international brands who are intending to launch themselves in the AFR market.
\end{abstract}

\section{Introduction}

India is positioned as a country with an evergreen, rich and varied heritage comprising numerous regions and states within having striking contrasts and enormous food habits, ideologies, beliefs, faiths, living standards, civilizations, traditions, geographic locations, climates, religions, ethnic and linguistic diversity. Traditionally, only North Indian and South Indian cuisine were popular in India.
Gradually, Chinese food made inroads and recorded steady growth. Over the years, restaurants serving international cuisine became more popular, such as Italian, Thai, Mexican and Mediterranean.

The market size of the food business of restaurants in India is estimated to be around Rs. 43,000 crores (2013). Today's consumers have exhaustive choices when it comes to choosing from where to dine out. Consumers 
are literally spoilt for choice when it comes to the food service industry. Apart from the unorganized restaurant sector comprising the roadside/ street food vendors, dhabas, mobile canteens and trolleys which are now very famous in every nook and corner of the tier II and tier III cities, consumers also have varied access to organized restaurants be it the Quick Service Restaurants (QSR's) / Limited Service Restaurants (LSR's)/ American Food Restaurants (AFR's), (Take away, home delivery or eat-in), Full Service Restaurants, PBCL (Pubs, Bars, Clubs and Lounges), casual dining, fine dining, food courts, retail food chain or the kiosks/carts (catering to special occasions-functions, marriages, birthdays, anniversaries). Quick Service Restaurants, are niche chains of restaurants with an international appeal recognized mainly by their ambience, hygiene and quality of food and services. They are responsible for 72.80 per cent of the whole industry revenues. Also, 7 per cent of the total restaurant market comprises of QSR's which account for Rs.3000 crores (www.nrai.org, www.rncos.com). Cafe Coffee Day (1090) and Dominos (364) are the largest AFR's in India in terms of reach and the number of outlets.

Also, increasing number of working professionals, working women family and busy life schedule with lack of time for cooking food, growing consumerism and increasing consumer demand for processed/ more convenient forms of food products like ready-to-eat and ready-to-use products, for tasty, nutritious, readily available and easily carried forms of innovative food products, long service hours of the restaurants has resulted in the growth of AFR's. Of late, it can be seen that there are several psychological factors that impulsively push the consumers into consuming American foods, the most important among them being, the lesser known but the most vital factor for any thriving business i.e., marketing. Most AFR's now-a-days make good use of a variety of permutation and combination to fix and match the marketing mix elements. AFR's are generally projected to customers as restaurants that have convenient locations, quick and efficient services, easily transportable food, good flavours, clean venues and giveaways. Most of the marketing is done either through television advertising, during youth-oriented shows and the most appealing and popular social media that makes use of several apps.

The growth of an AFR depends upon its popularity amongst the consumers and consumers perception depends upon various factors like price, quality etc...In order to keep the consumers loyal towards the restaurants, companies/ restaurateurs may have to come up with unique strategies apart from being dynamic and proactive apart from simultaneously delighting consumers, thereby responding to the ever changing trends in the consumer lifestyle and behavior.

Marketers can benefit from understanding the individual consumers behaviour over time. They can select their marketing actions that fit their consumer's patterns, commitment and behaviour and can identify and use actions to influence those patterns. Insufficient understanding can lead marketers into trouble.

This research work is useful to the AFR's for studying the awareness pattern of consumers, sources of information and how best they can sustain themselves in this competitive world to attract customers either through the use of media apart from sales forecasters and marketing managers in identifying their most preferred target group. This study will be helpful for the new entrants in the food service sector particularly for the local brands and future potential international brands who are intending to launch themselves in the AFR market. 


\section{Objectives of the study}

The available literature shows that there is bounteous scope for research in this area. This study is therefore an exploratory study that largely focuses on consumer awareness pattern about American Food Restaurants in Bengaluru city.

Accordingly, the study will highlight underlying issues such as consumer's preferred restaurants for consuming outside food, consumer's awareness of other AFR's, consumer's awareness of the different brands of AFR's, sources of information about American foods and AFR's among the consumers.

\section{Materials and Methods}

Bengaluru also known as the Silicon Valley located in the state of Karnataka was selected deliberately for the study, as it is home to a large number of American Food Restaurants (AFR) making it conducive for the study to be carried out. Both primary and secondary data accounted for a large contribution to the study.

Accordingly, data was collected in the primary form from 90 consumers of American style foods by personal interview method using a schedule during the year 2014-15. The mode of sampling was convenient and purposeful sampling. Seven AFR's have been chosen for the given study and these include restaurants. The data collected was analysed using tabular analysis and percentages were calculated to draw suitable conclusions.

\section{Results and Discussion}

The results have been tabulated and presented under suitable headings after it was collected from the sample consumer respondents in order to throw light on the major issues of the study.

\section{Consumption of outside food}

It could be observed from Table 1 that cent per cent of the consumers consumed outside food.

Consumer's preferred restaurants for consuming outside food

Consumer's preferred restaurants for consuming outside food can be inferred from Table 2.

It can be noticed that a little more than half of the consumers $(53.33 \%)$ preferred ethnic restaurants followed by one third of the consumers $(35.55 \%)$ who preferred Chinese restaurants.

American Food Restaurants were preferred by 30 per cent of the consumers while 8.88 per cent preferred other kinds of restaurants.

\section{Consumer's awareness of other American Food Restaurants}

The consumer's awareness of other American Food Restaurants is presented in Table 3. It is clear from the Table that, cent per cent of the consumers were aware of American Food Restaurants.

\section{Sources of information about AFR's among the consumers}

The sources of information for the consumers with respect to American Food Restaurants are presented in Table 5. It is clear from the Table that, about 64.44 per cent of the consumers were relying on information from advertisements which happened to be one of the major sources of information. The next important source was internet with 54.44 per cent, followed by point of display at the restaurant, television and friends/ relatives to the extent of 43.33 per cent each. 
Consumers were also getting information from sources such as pamphlets (35.55\%), print media (newspapers/ magazines) (33.33\%), colleagues $(22.22 \%)$ and hoardings $(18.88 \%)$. However, it is also clear from the Table that sources like others (that includes seminars, workshops, symposium and college lectures) with 12.22 per cent, radio $(10 \%)$ and neighbours $(6.66 \%)$ were reaching out to the least number of consumers.

\section{Consumption of outside food}

From the study, it was concluded that cent per cent of the consumers consumed outside food (Table 1). This indicates that Indians and in particular, Bengalurians have developed a taste for outside food. Also, nutrition transition, rapid socio-economic changes and westernization have significantly influenced the lifestyle and food habits of Bengalurian consumers. This has resulted in a great change in their eating habits, and American foods or outside foods have become an essential element in their diet. Due to the shift from extended to nuclear families, the proportion of people dining out has increased and in many cases AFR's may be the preferred places to dine. This could be due to reasonable prices, quick services, convenience and appropriate environment provided by AFR's. Hwang and Cranage (2010) and Musaiger (2014) also reported similar results in their study.

\section{Consumer's preferred restaurants for consuming outside food}

The consumers consume foods in different kinds of restaurants like restaurants with ethnic dishes of India, American style foods, Chinese foods and others. The consumers of American style foods also prefer restaurants offering ethnic foods and this constitutes half of the consumers. Significant findings have indicated that a little more than half of the consumers $(53.33 \%)$ preferred ethnic restaurants followed by one third of the consumers $(35.55 \%)$ who preferred Chinese restaurants.

American Food Restaurants were preferred by 30 per cent of the consumers while 8.88 per cent preferred other kinds of restaurants (Table 2). This indicates that there is a significant proportion of the population that still prefers consuming food at Darshini hotels and Udupi hotels.

The finding is also consistent with the fact that there is a western influence in India, enabling foreign brands/ products to perform well in the Indian market. International cuisine represents basic family appeal and attracts almost all consumers. Eating at AFR's has grown into a culture, after the popularity of giants such as McDonald's, KFC, Subway, Burger King etc. The results of the study are similar to the study conducted by Shoyemi (2014).

\section{Consumer's awareness of other American Food Restaurants}

Results have indicated that cent per cent of the consumers were aware of other American Food Restaurants (Table 3). Consumer behaviour characteristics of Bengalurians indicate that they have greater exposure through internet, T.V, mass media with many consumers considering that consuming American foods elevates their status and indicates their trendy lifestyle.

Degree of greater awareness of American Food Restaurants as compared to other restaurants indicates that wide publicity received in the media and aggressive advertisement strategies may be the reason for greater brand awareness among the consumers. The results of the study are similar to the study conducted by Shoyemi (2014). 
Table.1 Consumption of outside food ( $\mathrm{n}=90)$

\begin{tabular}{|c|c|c|c|}
\hline $\begin{array}{l}\text { Sl. } \\
\text { No. }\end{array}$ & Consumption of outside food & $\begin{array}{l}\text { Number of } \\
\text { consumers }\end{array}$ & $\begin{array}{l}\text { Percentage to the } \\
\text { total }\end{array}$ \\
\hline 1. & $\begin{array}{l}\text { Consumers who consume } \\
\text { outside food }\end{array}$ & 90 & 100 \\
\hline 2. & $\begin{array}{l}\text { Consumers who don't consume } \\
\text { outside food }\end{array}$ & 0 & 0 \\
\hline \multicolumn{2}{|r|}{ Total } & 90 & 100.00 \\
\hline
\end{tabular}

Table. 2 Consumer's preferred restaurants for consuming outside food $(n=90)$

\begin{tabular}{|c|l|c|c|}
\hline $\begin{array}{c}\text { SI. } \\
\text { No. }\end{array}$ & \multicolumn{1}{|c|}{ Preferred restaurant } & $\begin{array}{c}\text { Number of } \\
\text { consumers }\end{array}$ & Percentage \\
\hline $\mathbf{1 .}$ & Ethnic restaurants & 48 & 53.33 \\
\hline $\mathbf{2 .}$ & American Food Restaurants & 27 & 30.00 \\
\hline $\mathbf{3 .}$ & Chinese restaurants & 32 & 35.55 \\
\hline $\mathbf{4 .}$ & Any other & 8 & 8.88 \\
\hline
\end{tabular}

Note: Multiple responses were given by the respondent / consumer

Table.3 Consumer's awareness of other American Food Restaurants ( $\mathrm{n}=90)$

\begin{tabular}{|c|l|c|c|}
\hline $\begin{array}{c}\text { Sl. } \\
\text { No. }\end{array}$ & \multicolumn{1}{|c|}{ Awareness rate } & $\begin{array}{c}\text { Number of } \\
\text { consumers }\end{array}$ & $\begin{array}{c}\text { Percentage to the } \\
\text { total }\end{array}$ \\
\hline 1. & Aware & 90 & 100 \\
\hline 2. & Not Aware & 0 & 0 \\
\hline \multicolumn{2}{r}{ Total } & $\mathbf{9 0}$ & $\mathbf{1 0 0 . 0 0}$ \\
\hline
\end{tabular}

Table.4 Sources of information about AFR's among the consumers $(n=90)$

\begin{tabular}{|c|c|c|c|}
\hline 1. & Advertisements & 58 & 64.44 \\
\hline 2. & Internet & 49 & 54.44 \\
\hline 3. & Point of display / restaurant & 39 & 43.33 \\
\hline 4. & Television & 39 & 43.33 \\
\hline 5. & Friends / relatives & 39 & 43.33 \\
\hline 6. & Pamphlets & 32 & 35.55 \\
\hline 7. & $\begin{array}{l}\text { Print media (newspapers / } \\
\text { magazines) }\end{array}$ & 30 & 33.33 \\
\hline 8. & Colleagues & 20 & 22.22 \\
\hline 9. & Hoardings & 17 & 18.88 \\
\hline 10. & Others & 11 & 12.22 \\
\hline 11. & Radio & 9 & 10.00 \\
\hline 12. & Neighbours & 6 & 6.66 \\
\hline
\end{tabular}

Note: Multiple responses were given by the respondent / consumer 


\section{Sources of information about AFR's} among the consumers

Significant findings have indicated that, 64.44 per cent of the consumers were relying on information from advertisements which happened to be one of the major sources of information followed by internet, point of display at the restaurant, television and friends/ relatives. Consumers were also getting information from sources such as pamphlets, print media (newspapers/ magazines), colleagues and hoardings. However, sources like others (that includes seminars, workshops, symposium and college lectures), radio and neighbours were reaching out to the least number of consumers (Table 4).

This indicates that Bengaluru has a positive culture which responds to marketing. Marketing communication is an important strategy to advertise the restaurant or the food as the people get easily carried away by the information shown through advertisements.

Advertisements are one of the most important tools in mass media in today's world. Advertisements are attractive and advantageous because of their audio-visual effect, which renders the clear picturization about the information on different products and services. This in turn persuades the audience thereby influencing their brand awareness. In addition, the product manufacturers also promote their products through these advertisements which highly attracts the consumers to the maximum. Advertisements also affect the perception of the consumers and even to some extent get to influence their patronage. This also shows that AFR brands have done good marketing to create awareness. Also, the reach of the information is quite quick and it covers more number of consumers.
Usage of internet and online services is another very important method for AFR operators, to encourage consumers in making their consumption choiceand in influencing their brand preference. Internet, television, point of display at the restaurant and word of mouth through friends/ relatives are effective tools for consumers to search vacation destination restaurants. The product promotional strategies adopted by a producer would also strengthen the brand preference. Thus, the entrepreneurs who are starting new businesses in the restaurant market can make note that they can make use of such common purpose print media to attract more customers. Also, there is highest circulation of newspapers in Bengaluru in different vernacular languages. Usage of internet is also highest in this area and the cosmopolitan people of Bengaluru boasts of greater exposure to print and broadcast media. Hirekenchanagoudar (2008), Cunha et al., (2010), Shaikh (2010), Musaiger (2014) and Shoyemi (2014) reported similar results in their studies.

The study has unravelled several meaningful findings thereby acting as a yardstick for restaurateurs to work on. Cent per cent of the consumers consume outside food. Among the preference given for the choice of restaurants for dining out other than American Food Restaurants, a little more than half of the consumers $(53.33 \%)$ preferred ethnic restaurants followed by one third of the consumers $(35.55 \%)$ who preferred Chinese restaurants. Cent per cent of the consumers were aware of other American Food Restaurants.

Among the consumers patronizing American foods, 64.44 per cent of the consumers were relying on information from advertisements which happened to be one of the major sources of information. The next important source was internet with 54.44 per cent, 
followed by point of display at the restaurant, television and friends/ relatives to the extent of 43.33 per cent each.

\section{Practical utility}

To expand the reach to the customers, AFR's should increase their presence in social media and online platforms. After the recent success of online trading firms like Flipkart and Amazon, AFR's can take a futuristic initiative to improve their business.

The study itself is a valuable managerial and operation development tool, affording AFR's the opportunity to improve their competitiveness and service quality apart from designing new products and services and developing effective marketing strategies that fulfil consumer needs.

From among the several firms engaged in production and marketing of American foods, it can be seen that most of the fast food restaurants offer similar products or services. Hence, the consumers may have numerous options to choose from. Therefore, the way and the manner in which the AFR's raise awareness and publicize themselves apart from trying to capture the limelight are critical factors to the AFR's in gaining a competitive edge over their competitors. Awareness and knowledge of the American cuisines of each customer may differ. Hence, this information can be made use of in designing and developing new menus, cuisines and combo meals.

\section{Recommendations and Suggestions}

In the study, it is seen that the consumers came to know about AFR's from advertisements and internet and word of mouth was virtually less. This proves that two promotional methodologies were very effective and marketers should work on word of mouth. This can only happen when the consumers are satisfied with their experience and when they give a positive word of mouth feedback to their relatives and friends. This is the most effective form of communication when it comes to something edible as Indian consumers tend to trust people who have already consumed these foods.

\section{References}

Cunha, L. M., De Moura, A. P., Lima, R. C. and Frias, A., 2010. Valorisation of menu labelling at fast food restaurants: Exploring consumer perceptions. Brazilian Journal of Food Technology, 19(21): 55-64.

Hirekenchanagoudar, R., 2008. Consumer behaviour towards Ready-To-Eat food products. MBA (ABM) Project Report (Unpublished), University of Agricultural Sciences, Dharwad.

http://www.nrai.org/home.html http://www.rncos.com/reports.html

Hwang, J. and Cranage, D., 2010. Customer health perceptions of selected fast-food restaurants according to their nutritional knowledge and health consciousness. Journal of Foodservice Business Research, 13(2): 68-84.

Kumudha, A. and Thilaga, S., 2013. Buying behaviour of consumers with regard to soft drinks with reference to Coimbatore city. International Journal of Research in Computer Application \& Management, 3(11): 52-56.

Musaiger, A. O., 2014. Consumption, health attitudes and perception toward fast food among Arab consumers in Kuwait: Gender differences. Global Journal of Health Science, 6(6): 136-143.

Robson, S. K. A., 1999. Tuming the Tables: The Psychology of Design for HighVolume Restaurants. Cornell Hotel and Restaurant Administration Quarterly, 40(3): 56-63.

Rodríguez-Ibeas, R., 2007. Environmental 
product differentiation and Changing your view of the consumer. environmental awareness. European Journal of Marketing, 23(9): Environmental \& Resource Economics, 36(1): 237-254.

Shoyemi, A. O., 2014. Consumer's perception of International Quick Service Restaurants in Nigeria: A case study of Kentucky Fried Chicken (KFC). $M B A$ (International) Project Report (Unpublished), Dublin Business School., Nigeria.

Spawton, A. L., 1989. Grapes and wine Seminar-prospering in the 1990's: 6-48.

The Third Korea Youth Risk Behavior WebBased Survey, 2008. Ministry of Health, Welfare and Family Affairs. Korea Centers for Disease Control and Prevention, Seoul, p. 126-147.

Wein, E. E., Freeman, M. M. R. and Makus, J. C., 1996. Use of and preference for traditional foods among the Belcher Island Inuit. Arctic, 49(3): 256-264.

\section{How to cite this article:}

Pooja S. Bhat, T.N. Venkata Reddy and Mandanna, P.K. 2018. An Assessment of the Awareness Pattern of Consumers about American Food Restaurants in Bengaluru City. Int.J.Curr.Microbiol.App.Sci. 7(01): 982-989. doi: https://doi.org/10.20546/ijcmas.2018.701.118 